\title{
RELIGIOUS AUTHORITY AS HUMAN LIFE GUIDELINES
}

\author{
Ati \\ Civil Servant as Counselor of Islamic Affairs of Ministry of Religion Bandung, Indonesia \\ Email : ati.sriatika71@gmail.com
}

\begin{abstract}
This article was conducted to discuss the fading of the response of some people to religion. This response grew in line with emerge of various social phenomena of disappointment. Faith is also considered by some people to no longer be able to support the problem of life. Religion is deemed to be irrelevant to the demands of modernity. God and Religion in the perspective of some societies are then different from the views of the community in general. The authority of the life guidance held by humans is that religion is often only understood as a system of belief or belief in the teachings of God, which has implications for the understanding that religion is a theological doctrine. It is due to the cult of "religion" rather than understanding the "core" of the teachings of religion itself. Religion is only seen as "form" and not as "essence" that teaches submission to God, truth, justice, ethics, and morality.
\end{abstract}

Keywords: Authority, Religion, Life Guidelines

\section{A. INTRODUCTION}

Religion as part of primordial identity (Shani, 2014, p. 5) turns out to experience pressures from the current of globalization (Haynes, 1999, p. 126). Johan Meuleman said that there were three forms of response by Muslims to respond to the development of globalization and modernism, namely: an attitude of escape into, escape and critical openness (Meuleman, 1998).

Globalization means liberalization of trade and investment, regulation, privatization, adoption of democratic political systems and regional autonomy (Haque, 2002; Guttal, 2007) In other words globalization is neo-liberalism which essentially allows the market to work freely (A'la, 2006, p. 7). One form of religious resistance to globalization (Herrington, 2013) is the attitude to run into and reexplore ethical values to be used as a counter system (Beit-Hallahmi, 2003) against systems born of the flow of modernization and globalization (Pasha, 2000).

This resistance attitude then aroused the birth of religious fundamentalism movements (Lehmann, 1998), namely a change that tried to understand religion in a rigid and textual manner (CanettiNisim, 2003) and closed itself to various modern developments which were sustained by the power of rationality (Barkun, 2003). Although the mention of fundamentalism for a movement that wants to actualize religious teachings in social life (Ben-Dor \& Pedahzur, 2003) is very problematic and debatable, in general, these movements have the desire to make religion an ideological tool to oppose secular ideologies produced by modern society (Fox, 2003).

This resistance perspective then aroused the birth of spiritual Protestantism movements (Lehmann, 1998), particularly a campaign that attempted to know faith during a rigid and matter manner (Canetti-Nisim, 2003) and closed itself to numerous trendy developments that were sustained by the ability of rationality (Barkun, 2003). Though the mention of Protestantism for a movement that desires to actualize non secular teachings in social life (Ben-Dor \& Pedahzur, 2003) is hugely 
problematic and debatable, in general, these movements need to form faith associate degree philosophic tool to oppose lay ideologies made by contemporary society (Fox, 2003).

With a high militant attitude and sometimes spiced up with radical views, fundamentalism emerged (Koopmans, 2015) as a phenomenon that was born along with the pace of globalization, even as an inevitable part of the global system. Is this what is called the aspect of "religious revival" (Riesebrodt, 2000) in the common era or as a religious paradox we cannot just make judgments. Only perhaps what can be said is that the insistence of globalization has aroused people's longing for primordial values and attached cultural and religious identities that have long been uprooted from their roots (Machasin, 2009). Globalization, which has an extraordinary scope, is recognized or not has marginalized the joints of society rooted in traditions inspired by the breath of religion. Then returning to the bones of faith is a possible alternative to stem the pace of globalization, however paradoxical the religious movement that is (van der Vyver, 1996).

The second attitude that arises concerning globalization is an attempt to escape or over accommodative stance so that it is more of an impression of resistance (Nurullah, 2008). This attitude assumes that both within and outside the Western world, humans are developing towards a uniform and Western pattern of life (Abbas, 2011). It's just that the stages achieved by each region and society are different, but in the end, everything will arrive at the same pattern, namely the "modern" pattern (Inglehart \& Norris, 2009).

The attitude is expressed optimistically by Francis Fukuyama at The End of History and The Last Man, with his assumption that the peak of human history is to reach a single point, namely in the system of liberal democracy and capitalism. In other words, modernism which is supported by the global system is the estuary of the journey of human life. He states that liberal democracy as a system of government has covered the entire world in recent years, overcoming other ideologies such as monarchy, fascism, and communism. Moreover, Fukuyama argues that liberal democracy is "the endpoint of the evolution of human ideology" as "the end point of mankind's ideological evolution," "final form of human government" and because it is "the end of history." He also predicted that there would be no more major ideological conflicts at the end of history (Fukuyama, 2006).

This second view originated in the epoch of European enlightenment. The era was characterized by almost unlimited criticism of tradition and religion (Grote, 2014) along with a positive evaluation of the success of enlightenment thoughts (Aufklarung) and extraordinary optimism for the future of humans controlled by sovereign reason (Domínguez, 2017). Although European enlightenment thinkers were in no way not paying attention and even appreciating certain aspects of civilizations outside Europe, most of them assumed that European culture was the most advanced and brought about universal human reasoning that would bring all human beings to similar thoughts and civilizations (Israel, 2001, p. vi)

Although in different forms and contexts, in the following centuries the same view remained prominent, both in the idealist philosophy G.W.F. Hegel, materialism of Karl Marx, positivism of Auguste Comte, as well as in a number of descriptions in the fields of sociology, economics, and politics such as the theories put forward by Max Weber, W. Rostow, and Carl Deutsch. The influence of this view was also very much felt in the colonial policy, which, besides various other reasons, was also driven by a sense of rights and the obligation to "civilize" underdeveloped 
nations (A'la, 2003, p. 112). With this attitude, religion is only a decoration and lies rigid in a historical tomb (Warburton, 2012, p. 140) whose role is totally ignored and even considered as nothing at all. The way of thinking that denies the role of religion and strongly believes in this sovereign reasoning is for some people to be a very rational choice to follow, therefore religion should only occupy positions in places of worship alone and may not interfere in worldly life which is only open to rationality and empirical (Quiggle, 2008, p. 95).

The third attitude taken by religion to the contemporary world and the insistence of globalization is a critical attitude of openness, namely by not rejecting developments in the outside world, but also not surrendering blindly to them (Guénon, 2001, p. 62). The attitude, on the one hand, is aware of good and useful things from outside the tradition's environment and is happy to enjoy it, on the other hand is mindfu of its values and ideas and controls relations with the outside world on the basis of values and ideals (Mulkhan, 1992, p. 87).

The thought proposed in connection with the third attitude is an awareness that modernization in addition to having a negative impact turns out that there are also many positive values that can be taken as a reference in religion (Menhas, Umer, Akhtar, \& Shabbir, 2015). Many positive benefits of modernism are compatible with the values of religious teachings even religion must strive to guide the modernization so that it is always in line and continues to run on the tracks of spiritual truth (Iqbal, 2016). Refusing modernism blindly and not having a critical attitude to him will only give birth to a backward position and give birth to an intolerant attitude towards the identity and culture of other people (Parray, 2013; Iribarnegaray \& Jenkins, 2016). In the context of that discussion, this article was written.

\section{B. METHOD}

This article is written using library surveys (Jackson, 2005). The sources that were successfully tracked, which are related to the theme of the discussion in this article are cited, to complete data or sharpen analysis and interpretation of data. There are two primary references cited for writing this article, namely books (Mittman \& Borman, 1975, p. 5) and journal articles (Flynn, 1986, p. 313; Corti, Eynden, Bishop, \& Woollard, 2014, p. 203). Analysis and interpretation are carried out, in addition to the sources of the two sources, also based on the development of concepts and ideas carried out by the author himself.

\section{RESULT AND DISCUSSION}

Religion is often only understood as a system of belief or belief in the teachings of God so that it has implications for the understanding that religion is a theological doctrine. It is caused by the cult of "religion" rather than understanding the "core" of the teachings of religion itself. Religion is only seen as "form" and not as "essence" that teaches submission to God, truth, justice, ethics, and morals (Affifi, 2018).

It was alleged by some parties; this temporary religion was placed as a life guide that offered various principles of order about how humans live and where the ultimate goal of humans is. Every follower faith tends to obey and follow the teachings of the religion he believes. For example, Gibb in The Modern Trend in Islam states that every adherent of a religion should be submissive and obedient to the religious teachings he adheres to everyone must obey his or her own religious rules 
(Gibb, 1972). This view not only positions religion as a belief but also as a legal system (Mulkhan, 1992, p. 45).

Whereas Hassan Hanafi draws the direction of understanding to the hermeneutic pattern, namely the knowledge of religion should be placed on the relationship between consciousness and its object, namely sacred texts. According to him, religious understanding can be built on the basis of: first, historical awareness of the authenticity of a holy book and its originality; second, eidetic awareness that explains how we can understand the sacred text in a rational and logical way; and third, practical awareness as a form of theoretical framework that will bring human consciousness to essential truth (Prasetya, 2013).

We often see debates about religious teachings rather than understanding spiritual teachings. It was agreed or not, the emergence of a form of "liberal" understanding of religious teachings should not be considered a "war drum" against "fundamentalists." Non-literalist interpretations and reinterpretations of the understanding of religious teachings initiated by liberals are part of understanding spiritual teachings (Nashir, 2007, p. 160; Saidi, 2007, p. 205).

On the contrary, the view that religion is understood as a complete (kffah) belief or teaching through literal and dogmatic understanding also does not entirely give birth to the roots of fundamentalism. Because all forms of human interpretation of something excessive will become a justification and give birth to certain "ideologies" that consider themselves "right." Therefore to build a pluralistic awareness of religion, in the author opinion, we need to examine more deeply how we understand the underlying meaning of faith, the purpose of following religion and attitudes in religion (Farchan, 2016).

Religion is not only a piece of belief born of human will and consciousness towards God. Faith is also not just a belief system that carries legal messages formed from the reality of human history. The essential nature of religion is the basic guideline of divinity and humanity. In other words, how humans relate to God and how human relations with each other (Nasution, 2002, p. 65). If only there is an understanding that religion is born from the reality of human history in the past, this means that religion is merely an ancient building that is worth a museum. Religion is no longer a primary value that must be held as a guideline, but faith is seen only as a "monument" abstract about a belief. This phenomenon is the "bell of death" for the existence of religion and at the same time opens the opportunity for the appearance of an atheist attitude (Yusuf, 2012).

Likewise, if religion is only seen as a result of human thought engineering which contains the philosophy of divinity and humanity, then faith is just a pile of ideas in the human mind formed from the effects of imagination, spiritual experience and extraordinary sharpness of reason. Perhaps it is the precise human reason that in turn will be placed as a religion. It means that the authority of human motivation is seen as more capable of penetrating the essence of truth more than what is taught by God (Edge, 2013, p. 133). Is religion seen as a legal system?

If religion is seen as a legal system, it means that religion only teaches all forms of life guidelines for humans about norms and justice. A person can be claimed not to be religious or not practicing spiritual teachings when he does not obey religious laws. More extreme, say he has quit religion and then becomes mutually affirming or apostatizing. As I alluded to earlier belief was an essential guide to divinity and humanity (Horosz, 2012). 
This article tries to reiterate that impossibility a specific form of belief in others. It is contrary to the principles of religious freedom (the freedom of religion) in human rights. The misuse of fundamental ethical values caused by erroneous understanding can drag people to a map of conflict. Excessive religious fanaticism can arise because of understanding the narrow one towards religion. So there emerged religious fundamentalism and secular fundamentalists (Sharma, 2011, p. 74).

The excessive attitude in interpreting the teachings of religion has dragged some people or specific groups to the map of conflict in carrying out the necessity and submission to carry out religious teachings. In turn, this can lead someone to a particular form of spiritual awareness. From here, the seeds of sectarianism will be born in religion. Even though what needs to be observed is a form of inclusive consciousness that is humanist, open and tolerant (Maulana, 2017).

In Islam, it is taught that a form of general awareness is realized with mutual respect (tasāmuḥ). This principle of spiritual consciousness is based on the policy of freedom and tolerance for mutual openness and mutual respect for the religious rights of others. The opinion that this is in line with the principle that we must respect one's rights and freedoms in religion, but that must also be rights and religious freedom for others (Qomaruzzaman, 2018).

Religious pluralism in terms of the human rights approach lies in the extent to which humans understand the core teachings of religion that they adhered. Because all religions teach goodness and justice. In turn, all religions place ethical and moral principles as the primary and guiding principles for human life. Religious pluralism can be built not only based on mere knowledge and understanding but realized in a wise manner (Meuleman, 1998).

Therefore, the attitude of religious pluralism from the point of view of human rights can at least be based on the following principles: first, adhering to a religion is the fundamental human rights that humans have and in accordance with the nature of humanity itself; second, to understand as deeply as possible the understanding of religious teachings as a way of life that provides guidance for life; and third, a deep knowledge of spiritual teachings will lead to spiritual awareness and pluralist attitudes in viewing other religions (Madjid, 1995, p. 98).

Based on the hierarchical categorization of values in the category of universal values and particular values, religious significance is an integral part of universal values. It is based on the theological dimension itself as a transcendent-metaphysical. Ethical values are born values from the spiritual (psychological-religious) aspect of Muslim humans through their true and straight beliefs and experiences (hanif) to God. In this case, the Qur'an mentions:

And who is better than the person who is willing to give himself to God, while he is doing good, and he follows the straight religion of Abraham? And God took Abraham to be His favorite. (Q.S. Al-Nisā', 4: 125).

Spiritual value in the Islamic context accumulates in the concept of monotheism. Where in this concept, theological value functions as a world view that covers all the benefits in Islam. The idea of tawhid is a concept of a system of belief in God, but tawhid is also a value in Islam (Ahmad, 1991, p. 71). Tawhīd as the essence of theological value departs from human consciousness of the existence of God (theology) as a place of dependence (Allti al-Șamad), self-consciousness (anthropology) as an individual ('abd) and God's mandate (khalffah) that carries the mandate of 
God on earth and the cosmological world as a place for humans to carry out God's mission (Mulkhan, 1992, p. 87).

In this context, it is apparent that the religious values in the Islamic perspective precisely at the human level are quite theocentric (God-centered) nuances. While the philosophy of secular education views humans as too anthropo-centric, while in the view of Islamic teachings humans are understood to be theocentric beings. The look of humans as anthropocentric beings is only one of the essential aspects of the theocentric concepts of the Islamic Philosophy (Mastuhu, 1999, pp. $4,19)$. Nevertheless, the reality in God's view itself is the central issue of God's creation of everything that exists (all cosmic reality) is nothing but human (anthropological / micro-nature) itself.

The implication of monotheistic consciousness as a worldview (universal value order) in Islam for every Muslim individual gives birth to several values inherent and crystallized internally in the realm of knowledge. Awareness of the existence of God as a source of life will give birth to an attitude of submission and obedience due to science and faith which can reduce the nature of humility while elevating humanity to the nature of divinity. Whereas the awareness of his understanding as the creation of Allah's best created birth to a spirit of pious charity to prosper the earth by optimizing all human potential that is creative and innovative in observing and engineering cosmic reality (natural phenomena) through the process of studying science (Abdullah, 2010).

Relationships and attachments between God, humanity, and nature in Islamic theological discourse are quite clear. Awareness of interdependence like this in its actual level gives birth to and shapes religious values on Muslim students. In this cosmological order, students as the totality of creation feel the need for God's presence in the awareness of his life. The demand and dependence of the students on God is what makes human life meaningful (Faruqi, 2007). Without this awareness, consequently, human life becomes meaningless.

Awareness of the existence of God as a religious value in Islamic doctrine because it boils down to a view of life reflected in behavior (ethics) basically in a primordial manner has existed in all humans without exception (Muslim or non-Muslim). In this case, the Qur'an mentions:

And (remember), when your Lord took the descendants of the sons of Adam from their ribs, and God took a testimony against their souls (saying): "Am I not your Lord?" They replied: "Yes (You are our Lord); we are witnesses." (We do this) so that you do not say on the Day of Resurrection: "We (the children of Adam) are those who are unaware of this (oneness of God)." (Q.S. Al-A'rāf / 7: 172).

The awareness expressed by the Qur'an is an innate potential (heredity) known as fitrah. Knowledge and belief in the existence of God are fundamental needs in an empirical form can be stated, that humans always experience feelings of anxiety, fear, hope, helplessness and so on. Humans need a sense of security and certainty - humans, not yet from the dimension of the truth of God who is God. Therefore, the search and discovery of God is the culmination of the invention of religious needs. Thus, religion is not only seen from the dimension of function, but also in divinity in humans. However, this primordial awareness is not yet adequate, because it is still in the potential level (when the realm of the spirit) is not yet actually in the life behavior in the world. and again in the form of spiritual abstractions (Edis \& Bix, 2005). 
The awareness must play an active role in real life where humans have been able to play a role in determining the outlook on life, especially regarding the concept of God, especially the dimensions of God's truth. According to the Qur'an, human beings created by Allah have religious instincts, namely religion of monotheism, because according to Paulo F. Freire, the concept of education must be able to uncover and develop fundamental human awareness as the key to human understanding in the process of developing their world (Mastuhu, 1999, pp. 71-73).

At this level, making faith as the basis of God's view through the heart's eye (zawq) becomes imperfect. Teaching will be less tested, developed but less solid and not penetrate the mind, because without being supported by an understanding of God's majesty. The majesty of God can be observed in natural phenomena that are empirical through sensory observation (bașirah). It looks real. Information about this is stated by the Qur'an, including:

We will show them the signs (power). We are in all horizons and themselves, so it is clear to them that the Qur'an is right. And is your Lord not enough (for you) that He saw everything? (Q.S. Al-Fușșilat / 41: 53).

In this connection, as expressed by Mulkhan that the internalization of the theological value is expected to realize harmonious and appropriate warmth of relationships and the ropes between the motion of the world life immanent with the transcendent world. is an abstract framework of concrete and empirical human life (Mulkhan, 1992, p. 167). Thus it can be concluded that the religious value referred to in the context of the discussion of this thesis is the whole attitude and behavior of Muslim students reflecting an awareness of their presence in life so that it becomes a kind of marâji, personal ethical norms in every mobility of their lives. Where this value is obtained starting from family institutions, educational institutions and in social life (Rahman, 1994).

This understanding is also understood by Cak Nur, where according to him theological value (al-

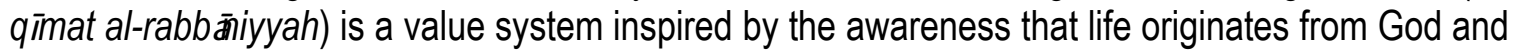
leads to God, then God in this order of values is of origin and purpose of life (Madjid, 1995, p. 1). In the Qur'an, it is explained:

They say, "We are from God, and we will return to Him." (Q.S. Al-Baqarah / 2: 156).

In summary, the religious value is the moral qualities of the human subjects of Muslim arising through intensive reflection on Divine attributes such as the Compassionate and Merciful, Forgiving, Just and others that are summarized in al-asmā' al-husnā Muslim students live up to these high values of independence, virtue, and morality.

Thus, the essence of religious value rests on monotheism. That is on the unity of God the existence of God as rabb and ilt in one full capacity. The awareness of the students about the position of God as a murabb in the universe is expected to deliver it to the sensitization to obey everything He commands. These are the two aspects of religious values, each of which values cognitive aspects; knowledge that God is al-Khtiq, affection aspect; the emergence of consciousness 'ubciliyyah, and the three psycho-motoric aspects; personification in attitude ('amaliyyah).

\section{CONCLUSION}

International Journal of Nusantara Islam Vol. 06 No. 02 2018: (154-164)

DOI: 10.15575/ijni.v6i2.4545 
The authority for life guidance held by humans is religion. However, it is often only understood as a system of belief or belief in the teachings of God, which has implications for the understanding that religion is a theological doctrine. This is caused by cult of "religion" rather than understanding the "core" of the teachings of religion itself. Religion is only seen as "form" and not as "essence" that teaches submission to God, truth, justice, ethics, and morals. It was alleged by some parties, this temporary religion was placed as a life guide that offered various principles of order about how humans live and where the ultimate goal of humans is. Every follower of religion has a tendency to obey and obey the teachings of the religion he believes.

The three religious attitudes in response to globalization have shown that religion is a part of human life that is quite unique which cannot be thrown away. It may be that someone rejects religion on a personal level, but there is a very perfect religious heritage on a collective level that cannot be denied. It will not be possible to understand and explain most of history and human culture without this inheritance. Religious traditions are often cultural matrices. Globally religious traditions are not only important cultural sources of the past, the wealth of their inheritance can give us another way that is just as important to think creatively in the present.

\section{REFERENCES}

Abbas, M. (2011). Globalization and the Muslim World. Journal of Islam in Asia, 8(spc.), 275-295. https://doi.org/10.31436/jia.v8i0.261

Abdullah, A. K. (2010). Strengthening Critical Thinking Skills Among Muslim Students. Islam and Civilisational Renewal (ICR), 1(4), 649-665.

Affifi, A. E. (2018). Chapter 4: The Rational and Mystical Interpretations of Islam. In K. W. Morgan (Ed.), Islam - The Straight Path: Islam Interpreted by Muslims (The Ronald Press Company, New York 1958. This material was prepared for Religion Online by Ted and Winnie Brock.). Retrieved from http://www.religion-online.org/book-chapter/chapter-4-therational-and-mystical-interpretations-of-islam-by-a-e-affifi/

Ahmad, A. (1991). Kerangka Dasar Masalah Paradigma Pendidikan Islam. In M. Usa (Ed.), Pendidikan Islam di Indonesia Antara Cita dan Fakta Suatu Pengantar. Yogyakarta: Tiara Wacana.

A'la, A. (2003). Dari Neomodernisme ke Islam liberal. Jakarta: Paramadina.

A'la, A. (2006). Pembaruan Pesantren. Yogyakarta: Pustaka Pesantren.

Barkun, M. (2003). Religious Violence and the Myth of Fundamentalism. Totalitarian Movements and Political Religions, 4(3), 55-70. https://doi.org/10.1080/14690760412331326230

Beit-Hallahmi, B. (2003). The Return of Martyrdom: Honour, death and immortality. Totalitarian Movements and Political Religions, 4(3), 11-34. https://doi.org/10.1080/14690760412331326210 
Ben-Dor, G., \& Pedahzur, A. (2003). The Uniqueness of Islamic fundamentalism and the fourth wave of international terrorism. Totalitarian Movements and Political Religions, 4(3), 7190. https://doi.org/10.1080/14690760412331326240

Canetti-Nisim, D. (2003). Two Religious Meaning Systems, One Political Belief System: Religiosity, alternative religiosity and political extremism. Totalitarian Movements and Political Religions, 4(3), 35-54. https://doi.org/10.1080/14690760412331326220

Corti, L., Eynden, V. V. den, Bishop, L., \& Woollard, M. (2014). Managing and Sharing Research Data: A Guide to Good Practice. Singapore: SAGE.

Domínguez, J. P. (2017). Introduction: Religious toleration in the Age of Enlightenment. History of European Ideas, 43(4), 273-287. https://doi.org/10.1080/01916599.2016.1203590

Edge, P. W. (2013). Religion and Law: An Introduction. Hampshire - Burlington: Ashgate Publishing, Ltd.

Edis, T., \& Bix, A. S. (2005). Biology and "Created Nature": Gender and the Body in Popular Islamic Literature from Modern Turkey and the West. The Arab Studies Journal, 12/13(2/1), 140-158.

Farchan, Y. (2016). Reasoning of Liberal Islam: A Study on Islamic Perspectives in Liberal Islam Network Jakarta. Analisa, 1(2), 180-198. https://doi.org/10.18784/analisa.v1i2.352

Faruqi, Y. M. (2007). Islamic View of Nature and values: Could these be the answer to building bridges between modern science and Islamic science. International Education Journal, 8(2), 461-469.

Flynn, R. (1986). An Introduction to Information Science. New York - Basel: CRC Press.

Fox, J. (2003). Counting the Causes and Dynamics of Ethnoreligious Violence. Totalitarian $\begin{array}{llll}\text { Movements and Political } \quad \text { Religions, } & \text { 119-144. }\end{array}$ https://doi.org/10.1080/14690760412331326260

Fukuyama, F. (2006). The End of History and the Last Man. New York - London - Toronto Sydney: Simon and Schuster.

Gibb, H. A. R. (1972). Modern Trends in Islam. New York: Octagon Books.

Grote, S. (2014). Review-Essay: Religion and Enlightenment. Journal of the History of Ideas, 75(1), 137-160. https://doi.org/10.1353/jhi.2014.0001

Guénon, R. (2001). The Crisis of the Modern World. New York: Sophia Perennis.

Guttal, S. (2007). Globalisation. Development in Practice, 17(4/5), 523-531.

Haque, M. S. (2002). Globalization, New Political Economy, and Governance: A Third World Viewpoint. Administrative Theory \& Praxis, 24(1), 103-124.

Haynes, J. (1999). Religion, Globalization and Political Culture in the Third World. New York: Springer. 
Herrington, L. M. (2013). Globalization and Religion in Historical Perspective: A Paradoxical Relationship. Religions, 4(1), 145-165. https://doi.org/10.3390/rel4010145

Horosz, W. (2012). The Liberal Commitment to Devine Immanence. In W. Horosz \& T. Clements (Eds.), Religion and Human Purpose: A Cross Disciplinary Approach (pp. 197-232). Dordrecht: Springer Science \& Business Media.

Inglehart, R., \& Norris, P. (2009). Muslim Integration into Western Cultures: Between Origins and Destinations. HKS Faculty Working Paper Series. https://doi.org/10.1111/j.14679248.2012.00951.x

Iqbal, A. (2016). Varied Impacts of Globalization on Religion in a Contemporary Society. Religio, 6(2), 2088-6330.

Iribarnegaray, D., \& Jenkins, B. (Bert. (2016). Islam and the West: Interplay with Modernity. Journal of Alternative Perspectives in the Social Sciences, 7(4), 516-548.

Israel, J. I. (2001). Radical Enlightenment: Philosophy and the Making of Modernity, 1650-1750. Oxford: Oxford University Press.

Jackson, P. A. (2005). Incoming International Students and the Library: a survey. Reference Services Review, 33(2), 197-209. https://doi.org/10.1108/00907320510597408

Koopmans, R. (2015). Religious Fundamentalism and Hostility against Out-groups: A Comparison of Muslims and Christians in Western Europe. Journal of Ethnic and Migration Studies, 41(1), 33-57. https://doi.org/10.1080/1369183X.2014.935307

Lehmann, D. (1998). Fundamentalism and Globalism. Third World Quarterly, 19(4), 607-634.

Machasin, M. (2009). Civil Islam as an Alternative to Islamic Fundamentalism. In Overcoming Fundamentalism Ethical Responses from Five Continents (pp. 207-225). Geneva: Globethics.net.

Madjid, N. (1995). Islam: Doktrin dan Peradaban. Jakarta: Yayasan Wakaf Paramadina.

Mastuhu. (1999). Memberdayakan Sistem Pendidikan Islam: strategi budaya menuju masyarakat akademik. Jakarta: Logos.

Maulana, D. (2017). The Exclusivism of Religion Teachers: Intolerance and Radicalism in Indonesian Public Schools. Studia Islamika, 24(2), 395-401. https://doi.org/10.15408/sdi.v24i2.5707

Menhas, R., Umer, S., Akhtar, S., \& Shabbir, G. (2015). Impact Of Modernization On Religious Institution: A Case Study Of Khyber Pakhtun Khwa, Pakistan. European Review Of Applied Sociology, 8(10), 23-28. https://doi.org/10.1515/eras-2015-0003

Meuleman, J. (1998). Sikap Islam Terhadap Perkembangan Kontemporer. In M. Ali, Agama Dalam Pergumulan Masyarakat Kontemporer. Yogyakarta: Tiara Wacana Yogya.

Mittman, B., \& Borman, L. (1975). Personalized Data Base Systems. New York: Melville Pub. Co. 
Mulkhan, A. M. (1992). Mencari Tuhan dan Tujuh Jalan Kebebasan: sebuah esai pemikiran Imam Al Ghazali. Jakarta: Bumi Aksara.

Nashir, H. (2007). Gerakan Islam Syariat: Reproduksi Salafiyah Ideologis di Indonesia. Jakarta: Pusat Studi Agama dan Peradaban Muhammadiyah.

Nasution, H. (2002). Teologi Islam: aliran-aliran sejarah analisa perbandingan. Jakarta: Penerbit Universitas Indonesia.

Nurullah, A. S. (2008). Globalisation as a Challenge to Islamic Cultural Identity. The International Journal of Interdisciplinary Social Sciences: Annual Review, 3(6), 45-52. https://doi.org/10.18848/1833-1882/CGP/v03i06/52625

Parray, T. A. (2013). Islamic Modernist and Reformist Thought: A Study of the Contribution of Sir Sayyid and Muhammad Iqbal. World Journal of Islamic History and Civilization, 1(2), 79 93.

Pasha, M. K. (2000). Globalization, Islam and Resistance. In B. K. Gills (Ed.), Globalization and the Politics of Resistance (pp. 241-254). https://doi.org/10.1057/9780230519176_15

Prasetya, M. A. (2013). MODEL PENAFSIRAN HASSAN HANAFI. JURNAL PENELITIAN, 7(2), 363-380. https://doi.org/10.21043/jupe.v7i2.819

Qomaruzzaman, B. (2018). Religious Inclusivity in Islamic Education Course Book of the 2013 Curriculum. MADANIA: JURNAL KAJIAN KEISLAMAN, 22(2), 195-210.

Quiggle, J. D. (2008). The Epistle of Jesus to the Church: A Commentary on the Revelation. Oregon: Wipf and Stock Publishers.

Rahman, M. (1994). A Holistic and Institutional Analysis of Islamic Education. American Journal of Islamic Social Sciences, 11(4), 519-531.

Riesebrodt, M. (2000). Fundamentalism and the Resurgence of Religion. Numen, 47(3), 266-287.

Saidi, Z. (2007). Ilusi Demokrasi: Kritik dan Otokritik Islam: menyongsong kembalinya tata kehidupan Islam menurut amal Madinah. Jakarta: Penerbit Republika.

Shani, G. (2014). Religion, Identity and Human Security. London - New York: Routledge.

Sharma, A. (2011). Problematizing Religious Freedom. Heidelbeg - London - New York: Springer Science \& Business Media.

van der Vyver, J. D. (1996). Religious Fundamentalism and Human Rights. Journal of International Affairs, 50(1), 21-40.

Warburton, D. (2012). Architecture, Power, and Religion: Hatshepsut, Amun \& Karnak in Context. Zurich - Berlin: LIT Verlag Münster.

Yusuf, H. (2012). EKSISTENSI TUHAN DAN AGAMA DALAM PERSPEKTIF MASYARAKAT KONTEMPORER. KALAM, 6(2), 215-234. https://doi.org/10.24042/klm.v6i2.404 
Religious Authority as Human Life Guidelines

International Journal of Nusantara Islam Vol. 06 No. 02 2018: (154-164)

DOI: 10.15575/ijni.v6i2.4545 